\title{
SYMBOL RELIGIJNY W LITERACKICH NIEORTODOKSYJNYCH UŻYCIACH. SZKIC O KULTUROWEJ ROLI PROFANACJI
}

\author{
Małgorzata Jankowska \\ Uniwersytet im. Adama Mickiewicza w Poznaniu
}

Kultura analizowana z perspektywy semiotycznej może być rozumiana jako sieć znaczeń, które są nieustannie wytwarzane, powielane i reinterpretowane przez jej użytkowników (Geertz 2005: 19, 63-64, 71, 111) ${ }^{1}$. W centrum tej sieci znajdują się przekazy kanoniczne (o czym szerzej nieco dalej), wsparte na wyjątkowo bogatych semantycznie symbolach. Przekazy te, na ogół o charakterze mitycznym lub religijnym, stanowiące same w sobie zamknięte całości, niedopuszczające już żadnych ingerencji, pobudzają mnogość interpretacji. Procesy egzegezy nie sprowadzają się jednak wyłącznie do instytucjonalnych czy teologicznych wykładni, lecz stanowią źródło inspiracji dla wszelkiego typu nieortodoksyjnych, heretyckich czy profanacyjnych ${ }^{2}$ odczytań. Odczytania te przyjmują nadto różnorodne formy - są to rozmaite „teksty kultury”, w poczet których zaliczyć można zarówno

\footnotetext{
Choć Geertz jest antropologiem, to jego rozumienie kultury określa się jako semiotyczne.

${ }^{2}$ Rozumienie herezji odnosi się tutaj do jej dwojakiego charakteru. Leszek Kołakowski tak pisze o tym zagadnieniu: ,,istotne jest w definicji heretyka, że chce on pozostawać w granicach odziedziczonego credo religijnego. [...] Heretyk, zarówno w oczach historyka, jak w oficjalnej doktrynie chrześcijańskiej, jest to zawsze ktoś, kto się odwołuje do tego samego kanonu, do tego samego źródła mądrości, do którego odwołują się ortodoksi czy też zwierzchnicy Kościoła, ale interpretuje ten kanon w inny sposób” (Kołakowski 2010: 11). Heretyk zatem to ten, kto za takowego uznany został przez dany Kościół, a zatem nie tylko sprzeniewierza się ortodoksji, ale też zostaje instytucjonalnie napiętnowany - ma więc herezja wymiar tak doktrynalny, jak i instytucjonalny (tamże: 15). Rozróżnienie to wpisuje się w tradycyjne rozumienie herezji jako „odrzucenia mniejszej lub większej części depozytu wiary” (św. Tomasz) czy też „błędnego ujęcia wiary, którego istota polega na tym, że jedna prawda (albo więcej prawd) zostaje wyrwana z organicznego kontekstu całości i w swojej izolacji fałszywie [fałszywie według poglądu instytucji chroniącej czystość doktryny] zrozumiana, albo też na negacji jakiegoś dogmatu" (Rahner, Vorgrimler 1987: 138). Nie jest tu istotne wnikanie w (przeprowadzane na gruncie katolicyzmu) rozróżnienie między herezją formalną (świadomym sprzeciwem wobec oficjalnej doktryny) a obiektywną (błędem nieświadomym), choć współczesne apokryfy literackie, stanowiące egzemplum dla zawartych tu rozważań, przypisać można z pewnością do tej pierwszej kategorii.
} 
literaturę i filozofię, jak i sztuki piękne, materiały audiowizualne, takie jak filmy i teledyski, dalej także komiksy, a nawet internetowe „memy”. Choć zawarte $\mathrm{w}$ niniejszym artykule analizy skupione będą przede wszystkim na tekstach literackich, to pamiętać należy, że wszelkie inne wytwory kultury zorientowane na nieortodoksyjne u̇́ycia symbolu religijnego realizuja (po części lub w całości) omawiane dalej mechanizmy.

Stojące w centrum przekazów kanonicznych symbole stają się zatem często obiektem reinterpretacji, przekształceń czy prób detabuizacji, w których to semantycznych przesunięciach ujawnia się ich złożony charakter. W dialektycznym sprzężeniu statyki tradycyjnych znaczeń i dynamiki coraz to nowszych kulturowych odczytań uwypukla się ich dwoistość, pozwalająca im na utrzymywanie się w samym centrum semiosfery (kulturowej sieci znaczeń).

Analizując takie właśnie nieortodoksyjne użycia symbolu, można uważniejszemu oglądowi poddać również rolę, jaką odgrywa on w procesach autokomunikacji kultury. To z kolei umożliwia dostrzeżenie mechanizmów pozwalających na zachowanie narracyjnego charakteru tejże kultury. Przekształcenia te wiążą się również ściśle z pracą pamięci kulturowej, dlatego ich uważniejszy ogląd może być wstępem do analizy systemów zbiorowego pamiętania i zapominania.

\section{/// Dwoistość symbolu. Perspektywa semiotyczna}

Choć symbol należy do zbioru pojęć najbardziej wieloznacznych i trudnych do zdefiniowania, to jednak, podejmując próby humanistycznej refleksji nad kultura, każda szkoła filozoficzna, antropologiczna czy

Profanację z kolei, za Giorgio Agambenem, rozumiem zarazem jako „użycie” tego, co religijne, w niereligijnym kontekście, jak uświęcenie tego, co przynależne tradycyjnie sferze profanum. Agamben zauważa ciekawą wieloznaczność łacińskiego słowa profanare, które z jednej strony odnosi się właśnie do „zeświecczenia”, z drugiej zaś do „poświęcenia” (choć to rozumienie bywa zapominane czy pomijane). Ten ciekawy związek znajduje swoje odzwierciedlenie także w koncepcji tak zwanego panmitologizmu, wnikliwie analizowanego przez Zarę Minc i Jurija Łotmana (por. Łotman, Minc, 1991), zasadzającego się właśnie na przenikaniu się obu sfer, profanacji sacrum i sakralizacji profanum. Odwołując się do Freuda, Agamben pisze: „, [termin sacer oznacza] zarówno «czcigodny, poświęcony bogom», jak i «przeklęty, wykluczony ze wspólnoty». To semantyczne rozmycie jest czymś więcej niż zwykłą dwuznacznością, można powiedzieć, że jest ono konstytutywne dla aktów profanacji i ofiary” (Agamben 2006: 99). Profanacja, zgodnie z tą optyką, oznacza zatem „przekazanie do użytku" - sakralizacja to proces oddawania rzeczy/słowa/języka we władanie bogów, profanacja zaś to przejęcie tejże rzeczy/słowa/języka przez ludzi. Profanacją w tym sensie będzie zatem użytkowanie symbolu/języka religijnego w tekstach nieprzynależących do uświęconego kanonu, nadto w tekstach częstokroć stojących na ideologicznych antypodach przekazu religijnego (wówczas może byłaby to swego rodzaju profanacja podwojona, nie tylko biorąca w użytek to, co boskie, lecz i intencjonalnie religijny symbol/język z aury boskości odzierająca). 
kulturoznawcza musi przyjać jakieś konkretne jego rozumienie. Z tego względu również semiotyczne analizy wybranego zbiorowego uniwersum znaczeń, w centrum zainteresowania stawiające między innymi tworzenie i przekształcanie istotnych kulturowo treści, muszą zawierać rozstrzygnięcia dotyczące istoty i funkcji mechanizmów symbolizacji.

Zdaniem Jurija Lotmana, głównego przedstawiciela tartusko-moskiewskiej szkoły semiotyki kultury, system semiotyczny, który nie podejmuje problematyki symbolu, pozostaje niepełny, a tym samym jego heurystyczny potencjał jawi się jako niewielki (por. Łotman 2008: 181). Zdając sobie sprawę ze złożonego charakteru zjawiska, semiotyk stwierdza, że wszelkie próby definicji powinny opierać się nie na stworzeniu jakiejś wyczerpującej charakterystyki, lecz na uogólnieniu kulturowo uwarunkowanych intuicji. Proponuje zatem, by rozumieć symbol jako ,ideę pewnej treści, która służy jako plan wyrażenia dla innej, z reguły kulturowo cenniejszej, treści” (tamże: 182). Tak ogólnie rozumiany symbol charakteryzuje się kilkoma własnościami, które pozwalają doprecyzować ujęte w tej skrótowej definicji pojęcie, a tym samym wyodrębnić je z ogółu semiotycznych terminów. W obszarze kulturoznawczych analiz z kolei cechy te pozwalają na w miarę precyzyjne wyłuskanie symbolu ze złożonego otoczenia tekstowego.

Jedną z najważniejszych jego własności jest to, że zarówno w planie treści, jak i wyrażania pozostaje tekstem zamkniętym i pełnym. Posiadając konkretne znaczenie i, co za tym idzie, granice, staje się on łatwo zauważalny na tle innych znaków czy tekstów (1). Ponadto zawiera się w nim zawsze „element archaiczny” - symbol jest w stanie przechowywać „w zwiniętej postaci" mnogość istotnych kulturowo treści, nawet wyjątkowo obszernych (por. tamże: 182) (2). To właściwość szczególnie istotna dla tożsamościowotwórczej funkcji, która spełnia w kulturze. Jako nośnik pamięci o mitach źródłowych, początkach wspólnoty, podstawowych wartościach i normach staje się rdzeniem, wokół którego nieustannie narastają kolejne warstwy kulturowych znaczeń. Będąc tak mocno ukonstytuowanym (własność 1) i archaicznym (własność 2), symbol z łatwością jednak wchodzi $\mathrm{w}$ nowe otoczenie tekstowe, tworzac $\mathrm{w}$ nim związki z innymi przekazami (przy zachowaniu semiotyczno-strukturalnej autonomii) (3). Z tym wiąże się kolejna istotna jego własność, a mianowicie, że „nigdy nie należy do jakiegoś jednego synchronicznego przekroju kultury - zawsze przeszywa ten przekrój pionowo, przybywając z przeszłości i odchodząc w przyszłość. Pamięć symbolu jest zawsze starsza niż pamięć jego niesymbolicznego tekstowego otoczenia” (tamże: 182-183) (4). Symbol zatem decyduje o kulturowym kontinuum, stanowiąc podstawę mechanizmu jednoczenia rozma- 
itych przekazów, scalania rozmaitych wartości oraz łączenia tego, co tradycyjne, z tym, co nowe. Tym samym nie pozwala kulturze rozpaść się na odseparowane od siebie, warunkowane czasowo i przestrzennie warstwy oraz zapobiega dezintegracji czy fragmentaryzacji doświadczenia kulturowego. Tę integrującą rolę symbolu umożliwia jego podwójna natura (5):

z jednej strony, przenikając złoża kultur, symbol realizuje się w swojej inwariantnej postaci. W tym aspekcie możemy obserwować jego powtarzalność. Symbol występować będzie jako coś niejednolitego w stosunku do otaczającej go przestrzeni tekstowej, jako posłaniec innych epok kulturowych (=innych kultur), jako przypomnienie o prastarych (=wiecznych) podstawach kultury. Z drugiej strony, symbol aktywnie koreluje z kontekstem kulturowym, transformuje się pod jego wpływem i sam go transformuje. Jego inwariantna istota realizuje się w wariantach. Właśnie w tych zmianach, którym ulega „wieczny” sens symbolu w danym kontekście kulturowym, kontekst ten najwyraźniej ujawnia swoją zmienność (tamże: 183).

Wejście w nowy kontekst pozwala symbolowi na ujawnienie drzemiacych w nim potencjałów semantycznych. Wpływa on bezpośrednio na znaczeniowy system, w który zostaje wpasowany, transformując na mocy

\footnotetext{
${ }^{3}$ Dla semiotycznej teorii kultury Lotmana ważna jest także koncepcja eksplozji, która może w pewnym stopniu kojarzyć się ze wspomnianą zmianą. Łotman pojęcie to stosuje do rozważań nad procesami historycznymi, traktując je jako uzupełnienie rozstrzygnięć historyków ze szkoły Annales. O ile Lotman zgadza się z proponowana przez francuskich badaczy wizją historiografii jako analizy procesów tak zwanego „długiego trwania” (la longue durée), o tyle dostrzega jej braki w zakresie omawiania tego, co w historii indywidualne, wyjątkowe, nieprzewidywalne. Semiotyk dostrzega konieczność uzupełnienia wizji stopniowego, w miarę harmonijnego rozwoju o momenty gwałtownej dynamizacji, nagłej zmiany, kulturowej lub historycznej eksplozji właśnie. Zauważa on jednak, że zmiana, która zachodzi w wyniku owego „wybuchu”, pociaga za sobą również pragnienie partycypacji i - co za tym idzie - naśladownictwa. Zjawisko to szczególnie zauważalne staje się w obszarze sztuki - trudno tu częstokroć odróżnić prawdziwą eksplozję właśnie od jej imitacji jako formy w gruncie rzeczy „antywybuchowej” (por. Lotman 1999: 28). Geniusz, jak pisze Łotman, może zapoczątkować nowy rozdział w historii sztuki, literatury, kultury, w którym partycypuja jego naśladowcy. Jeśli spojrzeć z tej perspektywy na problematykę apokryficzności, to uznać można, że zjawisko to wpisuje się raczej w procesy długiego trwania (podobnie jak i sam symbol, na co wskazuje jego, tak szczegółowo analizowana przez Lotmana, charakterystyka). Apokryficzność ma swoją wielowiekową historię, przez co kolejne skandalizujące odczytania kanonu wpisuja się raczej w osadzoną kulturowo tradycję, niż stanowią moment eksplozji. Podobnie interpretacje symbolu religijnego aktywizują zawarte w nim potencjały semantyczne, uruchamiając ponadto, za sprawą intertekstualnych nawiązań, tradycje egzegezy i wcześniejszych (często nieortodoksyjnych) reinterpretacji, wpisując się jednocześnie w kontekst zmian społeczno-kulturowych, które jednak wynikają z wcześniejszych „eksplozji”. Nadto dodać należy, że procesy długiego trwania i momenty eksplozji są ze sobą nierozerwalnie powiązane, zatem nie zawsze można łatwo oddzielić jedno od drugiego - mechanizmy te pozostaja pod wzajemnym wpływem (por. Lotman 1999: 37, 41-48).
} 
powiązań syntagmatycznych pozostałe elementy, a także, na mocy tej samej zasady, sam ulega przemianom. Szczególnie widoczne staje się to w obszarze profanacji, herezji czy zabiegów apokryficznych, w których to procesach uwypuklona zostaje jego zdolność do „,semiotycznej kooperacji” z innymi przekazami. Wykorzystywanie symbolu w tekstach częstokroć stojących na ,ideologicznych antypodach" kanonu wskazuje ponadto na nieustającą kulturową nośność treści źródłowych.

\section{/// Nieortodoksyjne użycia. Kanon a odstępstwo}

Wspomniana kulturowa ważność symbolu religijnego łączy się, jak już wskazano, z funkcją kanonu, będącego jednym z podstawowych narzędzi zbiorowej mnemotechniki.

Jan Assmann, analizując mechanizmy pamięci kulturowej, stwierdza, że pierwotny jej nośnik, rytuał, jest narzędziem najdoskonalej zachowującym treści źródłowe, gdyż nie dopuszcza żadnych przeinaczeń czy odstępstw. Będąc ściśle skodyfikowanym, określa warunki „dobrego pamiętania”, związane z rygorystyczną realizacją ściśle określonych gestów czy słów. Oparta na repetycji koherencja rytualna zostaje jednak zmarginalizowana jako medium pamięci z chwila pojawienia się pisma. Ten „wróg pamiętania” (Platon) z jednej strony „odciąża” członków zbiorowości, magazynując wszystkie istotne przekazy i symbole, z drugiej jednak rozluźnia ramy pamięci, dopuszczając przeinaczenia i ingerencje. To „rozprężenie” zostaje jednak zniwelowane z chwilą ukształtowania się kanonu, znikają bowiem wspomniane moźliwości ingerowania w zapisane treści. Dzieje się tak za sprawą przesunięcia znaczeniowego - kanon jest już nie tylko tym, co właściwe, lecz przede wszystkim tym, co święte, a tym samym niepodlegające redakcji (por. Assmann J. 2008: 102-118).

Peter Sloterdijk łączy rygor religijny z wymogiem żarliwości i oddania, a co za tym idzie - z logika jednej wartości, wynikająca ze specyficznie przepracowanej lekcji klasycznej logiki dwuwartościowej. W odrzucaniu mno-

\footnotetext{
${ }^{4}$ Zagadnienia związane z kanonem porusza również John B. Henderson (1991). Badacz wyróżnia trzy podstawowe cechy kanonu - zamknięcie/pełność, koherencję oraz wewnętrzną spójność czy niesprzeczność. Do tych trwałych cech każdego kanonu (Henderson analizuje przede wszystkim tradycję konfucjańską, którą zestawia z kanonem i komentarzami w tradycjach hinduistycznej, żydowskiej, chrześcijańskiej i muzułmańskiej) dodać można trzy kolejne, nieco mniej ogólne, a będą to: przekaz treści moralnych, wnikliwość tekstu oraz brak powierzchowności (co można czytać również jako złożoność). Proces kanonizacji tekstów badacz postrzega jako mechanizm stabilizowania się zbioru klasycznych i świętych tekstów, które zyskują charakter autorytatywnych, normatywnych przekazów, służących następnie m.in. celom politycznym i stanowiących ugruntowanie instytucji religijnych (tamże: 38).
} 
gości możliwości ujawniać ma się mechanizm ochronny kanonu - obrona prawdy objawionej przed wypaczeniami i dbałość o możliwie najdokładniejsze przechowanie mitów źródłowych:

[Gorliwe monoteizmy i ich uniwersalistyczne misje] opieraja się [...] na zamiarze wykluczenia wszelkim możliwym sposobem ryzyka błędu powodowanego przez drugą wartość wypowiedzi. [...] [C]hodzi w zasadzie tylko o misję wypędzenia ze świątyni jednowartościowości zuchwałych handlarzy wraz z ich zbędnym towarem. [...] Konieczność takiego podejścia narzuca się, gdy z racji pewnych wymogów ewolucji idei [...] ściśle jednowartościowa ontologia zostaje systematycznie spięta ze ściśle dwuwartościową logika. W tej konfiguracji może się po raz pierwszy pojawić zjawisko rygoru. [...] Myślenie staje się rygorystyczne, gdy zaczyna głosić, że tylko jedno z dwóch może być dla nas słuszne. [...] Logiczne źródło gorliwość ma w zliczaniu w dół do jedynki, która nie toleruje obok siebie nic ani nikogo. To Jeden jest matką nietolerancji. Wymaga radykalnego Albo, przy którym drugie Albo zostaje wykreślone (Sloterdijk 2013: 134-135).

Slotredijk, analizując tę specyficzną logikę monoteizmu (którą określić można też jako logikę kanonu), zauważa, że język dwóch wartości otwiera przestrzeń dla przeinaczeń, błędów, wątpliwości, a co za tym idzie - fałszu (postrzeganego jako taki z wewnątrz przekazu kanonicznego). Dlatego tak ważny jest wymóg ścisłości (tamże: 131-133). Do tej własności nawiązuje także Assmann, wiążący formułę kanonu z czterema figurami/strategiami. Pierwsza to figura świadka (najbliższy prawdzie przekaz o wydarzeniach), druga to strategia posłańca (wierny w obszarze treści i sensów przekaz wiadomości), trzecia - figura kopisty (wierny słowo w słowo przekaz tekstu), czwarta zaś to formuła umowy (wierne wypełnianie nakazów i zakazów) (por. Assmann J. 2008: 118-119). W tych czterech strategiach ujawnia się uspójniająca i uniwersalizująca rola kanonu, który traktuje o początkach wspólnoty/świata (świadectwo) i o znaczeniu tychże wydarzeń (posłaniec), przekazując wiernie prawdy i słowa objawione (kopista), które stają się automatycznie źródłem praw moralnych (umowa).

Dokładność i ścisłość stanowią zatem o kompletności i nienaruszalności kanonu. Co istotne jednak, taki zamknięty tekst (lub zbiór tekstów) wy- 
maga licznych dalszych nawiązań, interpretacji i objaśnień. Egzegeza jest niejako wtórnym warunkiem umożliwiającym danemu przekazowi funkcjonowanie w centrum kulturowego uniwersum znaczeń. Dopiero tekst poddany interpretacji staje się tekstem w pełni, tekstem wtaścinym.

Assmann zauważa, że chociaż kanon nosi znamiona świętości, to nie każdy tekst święty immanentnie do kanonu przynależy. Niekanoniczny tekst święty wymaga raczej recytacji, czyli repetycji, dopiero zaś tekst kanoniczny, który obejmuje swymi prawami, nakazami i zakazami całość życia społecznego, wymaga wyjaśnienia. Narastanie kolejnych tekstów (interpretacji, nawiązań itd.) skutkuje wyłonieniem się kanonów pierwszego i drugiego rzędu, a także literatury prymarnej i sekundarnej: „proces tworzenia kanonu tekstów prymarnych zaowocował powstaniem tekstów komentujacych i interpretujących, z których również wyłonił się kanon. W ten sposób pamięć kulturowa uformowała się z jednej strony w kanon pierwszego, drugiego i, w niektórych przypadkach, trzeciego rzędu, z drugiej zaś - w literaturę prymarną i sekundarną, teksty i komentarze. Najważniejszym etapem w procesie tworzenia kanonu był akt «zamknięcia» [...]. Wytyczał on dwie istotne granice: między kanonem i apokryfem oraz między tekstem prymarnym i sekundarnym” (Assmann J. 2008: 109).

Istnienie kanonu wyznacza zatem interpretatorowi rolę pośrednika między tekstem a odbiorca. Ma on za zadanie objaśnić tekst źródłowy w sposób możliwie najbardziej przejrzysty i wolny od wypaczeń. Tego typu interpretacje (jak przykładowo wykładnie teologiczne dotyczące Pisma Świętego, akceptowane przez dany Kościół chrześcijański) staja się zaczynem wspomnianego powyżej kanonu drugiego stopnia. Co jednak istotne, procesy nawiązań i interpretacji mogą być również źródłem tekstów apokryficznych czy heretyckich (to jest uznanych za takie przez „strażnika kanonu”, będącego w danej wspólnocie jedynym prawomocnym interpretatorem). Intertekstualne gry mogą zatem stać się zaczynem profanacji, sekundarną literaturą, charakteryzującą się dużym dystansem do mitu źródłowego. Wydaje się wręcz, że kulturowe trwanie każdego kanonu skutkować musi zarówno herezją i próbami detabuizacji, jak i dystansem do zawartych w nim treści i sensów.

Sloterdijk skazuje każdą wyczerpująca w zamierzeniu interpretację świętego tekstu na bluźnierstwo. Jedną opcja jest złudzenie nazbyt dobrego rozumienia tekstu, druga zaś uznanie go za absolutnie niezrozumiały, niejasny, a w efekcie - bezsensowny. Wyjściem z tego impasu jest „trzecia droga”, oparta na dystansie do przekazu źródłowego, czyli literatura: „[...] hermeneutyka religijna znalazła się a priori w przedziale między dwoma 
bluźnierstwami i musi tam dryfować. Nic lepiej nie motywuje do zaangażowania się w coś trzeciego. W pośrednim obszarze interpretacji wysiłek dobrze realizowanego rozumienia świętych znaków jest u siebie, a jego zasadnicza niedoskonałość stanowi jego szansę, jego żywioł. [...] [M]oże ona [owa pośrednia droga] prowadzić do granicy, na której tekst religijny rozpływa się w literaturę" (Sloterdijk 2013: 167).

Na podobny proces wskazuje Marc Augé, który uznaje, że realizacja mitu w innej, zdystansowanej do niego narracji jest procesem nieuchronnym, gdyż stanowi realizację potencjałów znaczeniowych zawartych immanentnie w kanonicznym źródle: ,[...] fikcyjne opowieści oddalają się od samych mitów, w których wszelako mają swe źródło, [...] w pewien sposób odłączają się od religii, powtarzając ja. [...] [Owo "przepisywanie mitu» rozumiane być powinno] nie jako produkt historycznej przypadkowości ani jako usunięcie mitu na rzecz literatury, ale jako jasne i proste działanie wewnętrzne: być może leży to w naturze każdej religii, ponieważ jej przeznaczenie jest ze swej strony narracyjne, pisane jej jest powielać się tylko przez zmianę natury" (Augé 2009: 52-53).

Mnogość nawiązań tekstowych, przyjmujących rozmaite formy, narasta właśnie z pojawiającym się w kulturze dystansem do mitu źródłowego - kanon pozostaje wciąż nośnikiem pamięci zbiorowej, nie stanowi już jednak „prawdy absolutnej”, a jego normatywna moc słabnie. Co oczywiste, w intertekstualnej grze z mitem źródłowym reinterpretacji czy nawet transformacji ulega stojący w jego centrum symbol.

\section{/// Transformacje symbolu religijnego}

W obszarze intertekstualnych nawiązań do kanonu wyróżnić można trzy podstawowe formy, to jest komentarz, naśladownictwo i krytykę .

Pierwsza strategia wiąże się próbami wyjaśniania zawiłych, tajemniczych, czasem hermetycznych znaczeń obecnych w tekście źródłowym, a zatem opiera się na uznaniu kanonu za zamknięty. Tego typu teksty wtórne traktują mity źródłowe jako paradygmaty tekstów kulturowych (por. Assmann A. 1995: 242), które, przez wzgląd na ich tożsamościowotwórczą rolę, wymagają szczególnego namysłu. Jest to również, wspomniana już przez Jana Assmanna, forma pośrednictwa między kanonicznym przekazem a jego odbiorca, między nadawca, czyli Absolutem, a członkami wspólnoty opartej na fundacyjnym micie.

\footnotetext{
${ }^{5}$ Podobną typologię stosuje J. Assmann, nie poświęca jednak zbyt wiele miejsca analizom tych strategii, koncentrując się przede wszystkim na formie hipolepsy.
} 
Naśladownictwo z kolei może przybierać rozmaite formy i być różnie motywowane. Może być to jedynie nawiązanie do stylistyki tekstów kanonicznych w celach estetycznych lub wykorzystanie zawartych w kanonie postaci, motywów czy wątków fabularnych dla celów narracyjnych czy ideologicznych. Może być to jednak również próba fałszerstwa. Tego typu tekst aspiruje do kanonu, a jego twórca może „podszywać się” pod autora tekstu źródłowego. Przykłady tego mechanizmu łatwo znaleźć w obszarze nawiązań do Pisma Świętego. O ile naśladownictwo pierwszego typu określić by można jako narrację apokryficzną, której odczytanie z góry zakłada nieautentyczność i grę z konwencjami kulturowymi, o tyle drugi typ nawiązań charakteryzować może tradycyjne apokryfy ${ }^{6}$, które w zamierzeniu twórców mają być czytane jako autentyczne teksty źródłowe. Odnajdywanie „tajemnych ksiąg” uzupełniających białe plamy kanonicznych przekazów to motyw często pojawiający się w literaturze i inaugurujący proces naśladownictwa. Jak pisze badacz apokryfów, Per Beskow, ,już w czasach starożytnych rozróżniano pomiędzy fantastycznymi a realistycznymi opowieściami o odkryciach ksiag. Opowieści o tych pierwszych znajdujemy w popularnej literaturze religijnej oraz beletrystyce, gdzie odnajdywanie ksiąg stanowi temat często spotykany; te drugie zaś charakteryzują się większym artyzmem i służą konkretnemu pozaliterackiemu celowi. To właśnie one zasługuja na miano fałszerstwa" (Beskow 2005: 16). Beskow łączy zatem apokryfy tradycyjne nie tylko z rzekomym sensacyjnym znaleziskiem, ale i z podszywaniem się pod autora któregoś

\footnotetext{
"Jak podkreślają liczni badacze zjawiska, termin ,apokryf” niełatwo jest zdefiniować, a to z tego względu, że próby ustalenia wyczerpujących kryteriów nigdy się nie powiodły. Apokryfy powstawały jeszcze w dobie formowania się ostatecznego kanonu Pisma Świętego, rozkwit tego typu piśmiennictwa przypadał na II wiek, w apokryfy obfitowały również wieki średnie. Apokryficzność w literaturze znalazła poczesne miejsce i rozwija się do dziś. Pseudonimia z kolei, która jest zabiegiem typowym dla tekstów apokryficznych, występowała również w Piśmie Świętym, a także w starogreckich traktatach filozoficznych i poezji. Niejednorodność gatunkowa i stylistyczna apokryfów również nie pozwala na jasne ich wyodrębnienie spośród innych tekstów. Podobnie tematyka - nawiązania do religijnych korzeni kultury Zachodu pojawiały się (i pojawiają nadal) w obszarze rozmaitych sztuk, także literatury. Przyczyny tworzenia tekstów apokryficznych sa równie zróżnicowane, co ich formy, stąd i w tym obszarze trudno o ostateczne rozstrzygnięcia i ustalenie mocnych kryteriów definicyjnych. Próbując dokonać rozróżnienia między tradycyjnymi apokryfami a narracjami apokryficznymi, oprzeć się można jednak na dwóch podstawowych kryteriach. Pierwszym jest czas powstania - pojęcie tradycyjnych apokryfów obejmowałoby głównie teksty z I-III wieku, choć do zbioru tego dołączyć można i teksty nieco późniejsze, w poczet współczesnych narracji apokryficznych zaliczyć można natomiast teksty tworzone w XX i XXI wieku. Drugim istotnym kryterium rozróżniającym jest stosunek do kanonu. Tradycyjne apokryfy aspirują bądź do kanonu już istniejącego, bądź do stworzenia nowego, w zamierzeniu są tekstami o charakterze religijnym, często przedstawiane są jako teksty natchnione słowem Bożym. Współczesne narracje apokryficzne natomiast uznają zamknięcie kanonu, nie aspirują do niego, a jedynie wykorzystują nośne kulturowo treści i symbole do własnych zróżnicowanych celów. Są to zatem stylizacje o charakterze świeckim.
} 
z tekstów kanonicznych - byłoby to zatem swoiste podwójne fałszerstwo. Jak jednak wskazuje inny badacz tematu, Ryszard Rubinkiewicz, pseudoepigrafia była swego czasu popularnym zabiegiem literackim, występującym nie tylko w apokryfach, ale i w samym Piśmie Świętym - w ramach przykładu przywołuje Pięcioksiag, który kształt ostateczny przyjął w V wieku przed Chrystusem, a który jednocześnie w całości postrzegany jest jako dzieło Mojżesza (Rubinkiewicz 1987: 11-12). Marek Starowieyski z kolei dodaje, że zabieg taki związany jest nie tylko z kultura judeochrześcijańska, występował bowiem również w klasycznej literaturze greckiej, a uzasadniony był potrzeba przydania ważności nowemu tekstowi poprzez odwołanie się do autorytetu rzekomego twórcy (Starowieyski 2006: 9). Kwestia autorytetu jest wyjątkowo istotna. Jeśli rozszerzyć to zjawisko nie tylko na autorów kanonicznych, lecz także na sam tekst i stojące w jego centrum symbole, to w procesie tekstualnych nawiązań do owych źródeł dostrzec można witalność i kulturową ważność kanonu. W tym kontekście nawet te teksty, które wykorzystują symbol religijny do propagowania treści całkowicie sprzecznych z „oryginałem”, paradoksalnie podkreślają jego funkcjonowanie w centrum kulturowego uniwersum znaczeń, a tym samym uwypuklają niemożność całkowitej ucieczki czy odcięcia się od religijnych korzeni (nawet jeśli dystans do mitu źródłowego jest już znaczny) $)^{7}$.

Trzecia formuła określająca intertekstualne relacje między kanonem a nowymi tekstami, krytyka, łączyć może obie omówione wcześniej strategie, czyli komentarz i naśladownictwo. Krytyka może zatem przyjmować tak postać racjonalnej analizy, naukowego rozbioru sensów podanych w tekście źródłowym czy filozoficznej debaty z wyłożonymi w kanonie prawdami, normami i wartościami, jak i literackiego naśladownictwa mitu źródłowego, skonstruowanego tak, by uwypuklić „,nonsensowność” czy „fałsz” kanonicznych treści i wizji świata.

Często krytyka, zwłaszcza w formie literatury, wymierza w kanoniczne treści ostrze humoru. Sloterdijk, z właściwą sobie niechęcią do systemów uniwersalistycznych, pisze: ,[...] humor rozwijający się w cieniu monoteizmów ma wiele wspólnego z humorem pod rządami dyktatur, gdyż wszelkie totalitarne systemy, zarówno religijne, jak i polityczne, prowokują ludowy rewanż na przymusowej wzniosłości. Humor może wprost stanowić

\footnotetext{
7 Przykładowo wykorzystywanie kanonicznych postaci, symboli i motywów w „obrazoburczym” pisarstwie José Saramaga (najbardziej znamienna będzie tu Ewangelia wedtug Jezusa Chrystusa) odczytywane bywa jako sposób nadawania propagowanym przez autora treściom znaczenia i powagi. Badaczka twórczości portugalskiego pisarza, Ewa Lukaszyk, pisze: „Będąc, jak sam twierdzi, ateistą, Saramago zmuszony jest myśleć religijnie, aby uniknąć zawieszenia w pustce braku znaczenia, niepowagi, błahostki, literatury zredukowanej do funkcji ludycznej” (Lukaszyk 2005: 11).
} 
szkołę wielowartościowości. [...] [P]owstaje efekt wyzwalający" (Sloterdijk 2013: 168). Humor może być jednak „poważny” i przyjmować postać parodii, która dla Agambena jest wyrazem pragnienia wzniosłości, mimo że skazana jest na „pozostawanie obok śpiewu”, czyli jedynie odbijanie blasku sacrum, do którego się odnosi (Agamben 2006: 54). Włoski myśliciel idzie nawet o krok dalej, stwierdzając, że wszelkie próby przełożenia świętego przekazu na język świecki muszą prowadzić do parodii, która jest ,jedyną stosowną formą misterium" - inne próby ujęcia tego, co niewyrażalne, osuwać się muszą „, kicz lub emfazę" (tamże: 56). Parodia łączyć ma świętość i zabawę, które tradycyjnie przynależą do porządku spoz̧a codzienności. W tym obszarze ujawnia się jednak nie obojętność (choć ujawnia się w nim dystans), lecz pragnienie przepracowania tego, co źródłowe, w celu dostosowania do nowego kontekstu kulturowego. To dlatego w profanacji i parodii ujawnia się „nowe zastosowanie” tekstów kanonicznych (tamże: 97).

Intertekstualne nawiązania różnego typu odczytywać można jako próby twórczego prz̨ekładu mitów źródłowych. Twórczy przekład sprawia, że w procesie translacji otrzymujemy nie prosty odpowiednik tekstu pierwotnego (to byłoby bowiem możliwe wyłącznie w języku formalnym), lecz nowy tekst, charakteryzujący się naddatkiem sensu. Przyrost znaczenia wynika nie tylko z niepełnej przystawalności dwóch języków, ale też z semantycznego bogactwa oryginału, które ujawnia się w procesie przekładu, będącego również pracą interpretacji (por. Łotman 2008: 73).

Analizując tekst kanoniczny z perspektywy semiotycznej, uznać można, że stanowi on kod kulturowy, z którego korzystaja coraz to nowsze teksty-komunikaty. Kiedy jednak (co bardziej przypomina rzeczywistą cyrkulację sensów w kulturze) nadawca nowego komunikatu operuje nie jednym kodem, lecz wieloma, tekst przezeń konstruowany stać się może źródłem całej mnogości nowych treści. Łotman podkreśla ponadto, że komunikat cechuje się „zorientowaniem na kod”, co oznacza, że kieruje zainteresowanie nie tylko na treść przekazu, na kolejne generowane za jego sprawa sensy, ale i na język, czyli sposób wyrażenia tychże treści. Jeśli odniesie się te rozstrzygnięcia do problemu nieortodoksyjnych użyćsymbolu religijnego, to można przyjać, że owe nowe teksty, powstałe na mocy twórczego przekładu, pożytkując kanoniczne symbole i język, utrzymują w centrum zainteresowania mity źródłowe. Jeśli spojrzeć na symbol, jak chce tego Łotman, jako na podstawowy nośnik pamięci kulturowej, to jego transformacje czy reinterpretacje (choćby były próba profanacji) stanowić będą mechanizm unarracyjniania i uspójniania tożsamości kulturowej. Za przykład przema- 
wiający na korzyść tej tezy służyć mogą współczesne nieortodoksyjne użycia figury Jezusa ${ }^{8}$.

Figura Jezusa z Nazaretu stanowiła zawsze problem dla wszelkich prób egzegezy, o czym świadczyć mogą chociażby spory chrystologiczne, toczące się w pierwszych wiekach chrześcijaństwa. Relacja między pierwiastkiem ludzkim i boskim stanowiła przedmiot wielu goracych debat, a niektóre z rozstrzygnięć stawały się zaczynem herezji (postrzeganych jako takie m.in. przez Kościół rzymskokatolicki). Gnostycyzm, subordynacjonizm, arianizm, semiarianizm, apolinaryzm czy adopcjanizm to tylko niektóre z idei, które narodziły się przy okazji prób „zinterpretowania” Chrystusa9. Jezus, jako nad wyraz żywotny symbol, wykorzystywany był ponadto do rozmaitych celów pozareligijnych. Jako „miejsce symbolicznej projekcji wielkich ideałów" (Kołakowski 2009: 46) odczytywany był między innymi jako mędrzec, mistrz cnoty i filozofii praktycznej ${ }^{10}$, republikanin i głosiciel moralności rewolucyjnej ${ }^{11}$, a nawet pierwszy socjalista czy komunista $^{12}$ (szerzej na ten temat: Sesboüé 2006, Guillet 1980: 76-81). Jako miejsce skrzyżowania mistyki i polityki figura Jezusa szczególne miejsce znalazła również w teologii wyzwolenia.

Figura Jezusa stanowi jądro rozlicznych profanacyjnych odczytań kanonu. Niektóre z nich podnoszą na nowo problem teodycei (jak przykładowo Ewangelia wedtug Jezusa Chrystusa José Saramaga, w której Jezus, jako ideał człowieka, sprzeciwia się Bogu, widzianemu jako zły demiurg) lub kwestię „słabego Boga” i upadku wiary (Nikos Kazantzakis w swym Ostatnim kusz̨eniu Chrystusa propaguje ideę Boga uwewnętrznionego i koncepcję

\footnotetext{
${ }^{8}$ Jako że figurę Chrystusa traktuję w niniejszym artykule wyłącznie jako przykład stawianych tez, traktuję problem wyjątkowo skrótowo, odwołując się tylko do niektórych odczytań, pojawiających się w kilku wybranych tekstach literackich. Szerzej na ten temat piszę w książce Narracje apokryficzzne w kulturze wspótczesnej (Jankowska 2011).

${ }^{9}$ Więcej na ten temat we wspomnianej powyżej książce Jankowska 2011: 162-168.

${ }^{10}$ Tak obrazuje Jezusa choćby Jean-Jacques Rousseau, który porównuje go z Sokratesem, niejako go przy tym wywyższając i dostrzegając element „boskości” Nazarejczyka w jego odwadze, nieustępliwości i wierności własnym przekonaniom. Jezus jawi się tutaj jako mistrz filozofii naturalnej i mędrzec, czyli nade wszystko - człowiek (por. Rousseau 1955: 149-150).

${ }^{11}$ Jak pisze badacz tej problematyki, Bernard Sesboüé: „[... [Ksiega prawdy albo religijny i polityczny katechizm prawdžiwego republikanina głosi, że «dewiza republiki jest wzniosła jak jej autor, którym jest Chrystus»; Ewangelia jest «najbardziej rewolucyjną księgą, jaka się ukazała». [...] Katechizm robotnika, podobnie jak broszura [...] Demokrata chræésicijański albo ewangeliczny podręcznik. Wolności, Równości $i$ Braterstwa przypominaja, że Jezus uznawał się za robotnika i że wybrał swoich uczniów spośród pracujących: «Bracia robotnicy, których pracowite ręce współdziałają z wysiłkami rozumu przy wspólnym dziele pomyślności społecznej, zrozumcie i odnieście do Chrystusa całą wasza godność! Albowiem ewangelia uczy nas, że Syn Maryi był najpierw robotnikiem, a tym samym nauczając prawa pracy i uświęcając je swoim przykładem» (Demokrata cbrzéscijański, s. 95)" (Sesboüé 2006: 68-69).

12 Jak przykładowo: „Jedna prosta rzecz, ważna dla historii i nie dająca powodu do krytyki: otóż Jezus był komunistą" (Proundhon 1951, cyt. za: Sesboüé 2006: 76).
} 
człowieka jako Salvator Dei). Inne jeszcze lansują wizję chrześcijaństwa jako totalitarnego systemu politycznego, uprzywilejowującego określone grupy społeczne, będącego ponadto niczym więcej jak stojącą na antypodach rozumu manipulacją i fantasmagorią (taką wizję odnaleźć można chociażby w powieści Dobry çłowiek Jezus i totr Chrystus Philipa Pullmana). Postać Jezusa pojawia się również w tekstach będących literacką analizą kulturowej płynności, nieokreśloności czy synkretyzmu religijnego (przykładowo w Balladynach i romansach Ignacego Karpowicza), a także w powieściach-manifestach, dostrzegających szansę na etyczne projektowanie życia społecznego w ponownym upolitycznieniu religii (Panna Ferbelin Stefana Chwina). Jezus we współczesnych użyciach często obnaża „absurdy wiary”, stając po stronie specyficznie (bo scjentystycznie) pojmowanego racjonalizmu oraz pooświeceniowej etyki, opartej na samoodpowiedzialności jednostki żyjącej „pod pustym niebem”. Bywa też antyklerykałem, obnażającym nadużycia Kościoła. Zdarza mu się symbolizować zreinterpretowane Nowe Przymierze, które jest przejściem od strategii wzbudzania lęku do polityki miłości.

W licznych „nowych apokryfach” figura Jezusa wykorzystywana jest do propagowania takich idei, jak choćby wegetarianizm, życie w zgodzie z natura, ekologia. W Ewangelii Świetych Dwunastu znajdujemy rzekome nauki Nazarejczyka o konieczności miłowania zwierząt i zakazie jedzenia mięsa (a także twierdzenie o tym, że oryginalnie Ewangelie zawarte w Nowym Testamencie takie właśnie nauki zawierały, lecz przy ostatecznej redakcji kanonu zostały usunięte). Ta „biblia wegetarian”, po raz pierwszy wydana najprawdopodobniej w 1901 roku, była wielokrotnie wznawiana, a jej dystrybucja odbywała się między innymi w sklepach ze zdrową żywnościąa ${ }^{13}$. Podobną wymowę ma, wydana po raz pierwszy w 1937 roku, Ewangelia Pokoju (zwana początkowo Ewangelia Pokoju wedtug ucznia Janowego, kolejne wydania, uzupełnione o dodatkowe dwie księgi, które ukazały się po raz pierwszy w 1974 roku, nosiły tytuły - Ewangelia esseńczykón w wersji brytyjskiej oraz Esseńska Ewangelia Pokoju w wersji amerykańskiej (Beskow 2005: 151)), której rzekomego odkrycia dokonał Edmond Bordeaux Székely. Tekst ten zawiera nauki nie tylko o Bogu Ojcu, ale też o Matce Ziemi. Konieczność okazywania obu bóstwom (por. tamże: 162) równego szacunku prowadzi

\footnotetext{
13 Analizy tego tekstu dokonuje Per Beskow, pisząc: „Przyjacielski Jezus, który błogosławi i chroni rośliny i zwierzęta; Jezus, do którego ptaki i wszelkie inne stworzenie w naturalny sposób lgnie czy nie takim wielu z nas chciałoby Go widzieć? Wielu pociaga portret Jezusa nakreślony w Ewangelii Świętych Dwunastu - twierdzą oni, że zawarte w niej ideały oraz etyka przewyższają ideały i etykę kanonicznych Ewangelii” (Beskow 2005: 123). Badacz szczegółowo omawia również historię rzekomego odnalezienia tej „tajemniczej księgi” w tybetańskim klasztorze w 1881 roku przez niejakiego G.J.R. Ouseleya (por. zwłaszcza s. 124-125).
} 
do uznania troski o zasoby naturalne za moralny obowiązek człowieka. Z kolei w Ewangelii Wodnika, autorstwa Leviego H. Dowlinga, Jezus nie tylko troszczy się o ziemskie zasoby i zdrowe żywienie, ale też zapowiada nadejście nowej ery - ery Wodnika właśnie, a także - nowej religii. Tekst umieszcza Nazarejczyka w Indiach, nadając mu cechy hinduskiego guru, mistrza medytacji i mędrca, który naucza między innymi o reinkarnacji. Jezus to wędrowiec poszukujący mądrości i oświecenia, odwiedzający innych mędrców i nauczycieli, poznający rozmaite duchowe tradycje. To w końcu figura łącząca to, co ziemskie, z tym, co nie tyle „boskie”, ile kosmiczne. To figura symbolizująca odrodzenie ludzkości w duchu nowej ery pokoju i wolności (por. tamże: 137-146).

Tego typu użycia figury Jezusa zachowują jeszcze kontakt z sacrum (choć rozumianym niezgodnie z doktryną chrześcijańska), bywa jednak Jezus także wyjętym z obszaru świętości kulturowym artefaktem, symbolem źródeł zachodniej tożsamości, historycznym rdzeniem cywilizacji z jej dokonaniami w dziedzinie sztuk pięknych, architektury, muzyki, literatury czy teatru (por. np. Kołakowski 1989: 1-13). Jak pisze Kołakowski:

O Jezusie przeczytać można, co się chce.

Na przykład, że nigdy nie istniał.

Albo że owszem, istniał, lecz nie został ukrzyżowany; ktoś inny zawisł na krzyżu na jego miejscu.

Albo że owszem, został ukrzyżowany, ale nie umarł, lecz ocknął się w grobie, skąd wyszedł, by umrzeć po kilku dniach.

Albo że razem z żoną swoją Marią Magdaleną wyemigrował do Marsylii i miał tam dzieci, z których potomstwa powstać miała dynastia Merowingów.

Albo że był magikiem, który różnymi sztuczkami oszałamiał łatwowierną publiczność.

Albo że był przybyszem z innej galaktyki.

Albo że był zwykłym nacjonalistą żydowskim, antyrzymskim konspiratorem. 
Albo że był bytem bezcielesnym.

Albo że był homoseksualistą, a Jan Apostoł jego kochankiem.

Albo że był zarazem mężczyzną i kobietą.

Albo że należał do rewolucyjnej Nowej Lewicy.

Albo że główna sprawa, o którą chodzi w Ewangeliach, to jak robić pieniądze (słyszałem to na własne uszy od jednego z kaznodziejów telewizyjnych) (Kołakowski 2009: 127).

Filozof zauważa (a jego intuicje pokrewne są rozstrzygnięciom Łotmana), że symbol religijny pełni doniosłą rolę w kulturze przez wzgląd na swoja pojemność semantyczną i że nie sposób dociec, która jego interpretacja jest „słuszna” czy „prawomocna”, a która nie: „Chrystus czcigodny obraca się jak chorągiewka na wietrze, gnie się jak zwykłe sukno - mówił pisarz średniowieczny, Gotfryd ze Strasburga. - [...] Wszystkiemu się poddaje i do wszystkiego nagina, stosownie do serca każdego, równie dobrze do tego, co uczciwe, jak do oszustwa [...]. Jest zawsze tym, czym się pragnie, by był”' (1967: 244-245).

\section{/// Uchronić przed zapomnieniem. Kulturowa rola nieortodoksyjnych użyć symbolu}

Nawet w heretyckich czy antyreligijnych odczytaniach symbol realizuje swoje potencjały znaczeniowe i tożsamościowotwórcze - będąc używanym w tekstach lansujących odmienne od kanonicznych wartości, filozofie czy polityki, ujawnia swój kulturowy autorytet. „Przekodowany” za sprawa nowego języka symbol nie tylko pojawia się w nowych użyciach, lecz również wchodzi w relacje z mnogością innych tekstów. W tym złożonym, bogatym konglomeracie co prawda wyróżnia się, zachowując swoją tożsamość i silnie zaakcentowane granice, a tym samym jaśniejąc na semiotycznym firmamencie pośród bardziej „rozmazanych” lub uboższych semantycznie znaków, z drugiej strony jednak wchodzi $\mathrm{w}$ interakcje i, będąc uźywanym, obrasta w kolejne znaczenia, aktywujące się w swoistym tekstowym kolażu i w akcie twórczego przekładu. Symbol zatem zmienia się, pozostając zarazem niezmiennym. Paradoks owej podwójnej natury pozwala na wspomnianą uprzednio konstytucję narracyjnego charakteru kultury, któ- 
ra, pozostając kontinuum, zachowuje wszelkie swoje wcześniejsze teksty, wzbogacając się jednocześnie o nowe.

Nieortodoksyjne użycia symbolu pokazują, że dystans do mitu źródłowego nie sprawia, że zostaje on unieważniony jako istotny tekst kultury pozostaje on nadal w jej centrum, co skutecznie zapobiega jej rozchwianiu czy rozpadowi. Wszelkie takie transformacje czy reinterpretacje kanonu nie tylko jednak wykorzystuja jego kulturową nośność, lecz również ją wspomagaja - każde kolejne odwołanie się do źródła przyczynia się do utrzymywania go w centrum zainteresowania.

Symbol, by pozostawać żywotnym, musi być nieustannie w użyciu. Jak już wskazano, z punktu widzenia semiotyki kultura jest siecią znaczeń, nieustannie konstruowanych i przekazywanych w procesie interakcji między poszczególnymi jej członkami. Proces ciagłej semiozy musi być jednak osadzony w pewnych ramach, wyznaczanych przez pracę zapominania. Ujmując rzecz metaforycznie - pojemność pamięci (także kulturowej) jest ograniczona, dlatego nowe teksty, symbole i znaczenia wypieraja te bardziej archaiczne, postrzegane już jako ,nieprzydatne” czy mało istotne. Nadmiar danych wymusza usuwanie części informacji z obszaru zainteresowania, jeśli doświadczenie kulturowe ma pozostać spójne i sensowne. Zapominanie zatem jest niemożliwą do usunięcia składowa pamięci, ma za zadanie wspomagać ją i „usprawniać”. Te przekazy, które mają być utrzymane w centrum kulturowego uniwersum znaczeń, które mają być zapamiętane, muszą być zatem nieustannie powielane i odczytywane, choćby w sposób pośredni - inaczej czeka je zapomnienie. Znaczenie tej dynamiki podkreśla Jan Assmann, w pełni świadom tego, że tekst czy symbol niekomunikowany przestaje pełnić znaczącą rolę w kulturze i zepchnięty zostaje w obszar semantycznych nieużytków. To dlatego, zdaniem badacza, rytuał jawić się może jako pewniejsza forma upamiętniania, polega bowiem na nieustannej repetycji, ,natomiast martwa litera tekstu istnieje materialnie również poza nią [cyrkulacja] i łatwo może wyjść z obiegu. Kiedy zaś tekst wyjdzie z użycia, staje się raczej grobem niż skarbnicą sensu, który wówczas może zmartwychwstać tylko dzięki wysiłkowi interpretatora, sztuce hermeneutyki i pośrednictwu komentarza" (Assmann J. 2008: 106).

Przywoływanie symbolu religijnego, choćby w antyreligijnym kontekście, pełni zatem kluczową rolę w utrzymywaniu go w pamięci kultury, zwłaszcza w sytuacji rosnącego dystansu do mitów źródłowych. Dlatego nawet nieortodoksyjne, profanacyjne, heretyckie teksty, wykorzystujacc symbol religijny, przyczyniają się do jego (re)witalizacji i uniemożliwiaja jego desemantyzację, przejście w obszar zapomnienia. 
Kultura, autokomunikując się w ten sposób, wydobywa kolejne potencjały tkwiące w niej samej, w jej symbolice źródłowej, gdyż: „znaczeniowe potencje symbolu są zawsze szersze od ich danej realizacji: związki, w jakie wstępuje symbol za pomocą swego wyrażenia z tym lub innym semiotycznym otoczeniem, nie wyczerpują jego wszystkich możliwości w tym zakresie. Właśnie to tworzy tę znaczeniową rezerwę, za pomocą której symbol może wstępować w nieoczekiwane związki, zmieniając swoją istotę i deformując w nieoczekiwany sposób tekstowe otoczenie" (Lotman 2008: 184).

Rzecz jasna w sytuacji, w której dany symbol czy mit zdążył już popaść w zapomnienie, jego użycie rzadko skutkować będzie przywróceniem mu uprzedniej witalności - będzie już raczej wyłącznie mnemotechniczną gra, pamiecia o pamięci, mglistym wskazaniem na zmurszałe kanony. Nawet w takim przypadku jednak symbol lub mit zyskuje nowe znaczenie, przez uruchomienie niektórych z jego potencjałów - choćby właśnie znaczenie kulturowego memu.

Przywołanie symbolu religijnego może mieć zatem różne cele - może być próbą ustanowienia nowego kanonu, może stanowić estetyczną lub intelektualna grę z konwencjami kulturowymi, może być próbą zbudowania nowej filozofii, metodą kreowania nowych światopoglądów, które świecić chcą odbitym blaskiem dotychczasowego autorytetu, może być to próba obalenia tabu, wywołania skandalu lub efekt politycznych czy społecznych dążeń. W każdym z tych przypadków jednak (a nie wyczerpują one całej gamy możliwych motywacji leżących u podłoża nieortodoksyjnych użyc) nowe teksty wzmacniają wykorzystany symbol (nawet jeśli czynią to niejako wbrew własnym intencjom) i podbudowuja jego kulturową nośność, przyznając mu poczesne miejsce w panteonie najbardziej wpływowych kulturotwórczych znaków. W procesie tym symbol ujawnia swój wspomniany już dwoisty charakter (statykę tradycji i dynamikę semiotycznej innowacji), uwypuklając tym samym zogniskowaną w nim kulturową potrzebę spójności.

Bibliografia:

/// Agamben G. 2006. Profanacje, tłum. M. Kwaterko, Państwowy Instytut Wydawniczy, Warszawa.

/// Assmann A. 1995. Was sind kulturelle Texte?, [w:] Literaturkanon-Medienereignis - kultureller Text. Formen interkultureller Kommunikation und Übersetzung, red. A. Poltermann, Erich Schmidt Verlag, Berlin. 
/// Assmann J. 2008. Pamięć kulturowa. Pismo, zapamietywanie i polityczna tożsamość w cywilizacjach starożytnych, tłum. A. Kryczyńska-Pham, Wydawnictwa Uniwersytetu Warszawskiego, Warszawa.

/// Augé M. 2009. Formy zapomnienia, tłum. A. Turczyn, Universitas, Kraków.

/// Beskow P. 2005, Osobliwe opowieści o Jezusie. Analiza nowych apokryfów, tłum. J. Wolak, Wydawnictwo WAM, Kraków.

/// Geertz C. 2005. Interpretacja kultur. Wybrane eseje, tłum. M.P. Piechaczek, Wydawnictwo Uniwersytetu Jagiellońskiego, Kraków.

/// Guillet J. 1980. Jezus Chrystus w naszym świecie, tłum. E. Szwarcenberg-Czerny, Instytut Wydawniczy PAX, Warszawa.

/// Henderson J.B. 1991. Scripture, Canon and Commentary. A comparison of Confucian and Western Exegesis, Princeton University Press, Princeton.

/// Kołakowski L. 1967. Symbole religijne i kultura bumanistyczna, [w:] tegoż, Kultura i fetysže. Zbiór rozpraw, Państwowe Wydawnictwo Naukowe, Warszawa.

/// Kołakowski L. 1989. Jezus Chrystus - prorok i reformator, [w:] tegoż, Pochwata niekonsekwencji. Pisma rozproszone z lat 1955-1968, t. I, Niezależna Oficyna Wydawnicza, Warszawa.

/// Kołakowski L. 2009. Nasza sprawa wieczna z. Jezusem, [w:] tegoż, Czy Pan Bóg jest szeczéśliny i inne pytania, Wydawnictwo Znak, Kraków.

/// Kołakowski L. 2010. Herezja, Wydawnictwo Znak, Kraków.

/// Lotman J. 1999. Kultura i eksplozja, tłum. B. Żyłko, Państwowy Instytut Wydawniczy, Warszawa.

/// Lotman J. 2008. Uniwersum umystu. Semiotyczna teoria kultury, tłum. B. Żyłko, Wydawnictwo Uniwersytetu Gdańskiego, Gdańsk.

/// Łukaszyk E. 2005. Pokusa pustyni. Nomadyzm jako wyjście z kryzysu wspótczesności w pisarstwie José Saramago, Universitas, Kraków.

/// Proudhon P.J. 1951. Portreit de Jésus, Flore, Paris.

/// Rahner K., Vorgrimler H. 1987. Mały stownik teologiczny, Instytut Wydawniczy PAX, Warszawa. 
/// Rousseau J.-J. 1955. Emil, czyli o wychowaniu, tłum. W. Husarski, Ossolineum, Wrocław.

/// Rubinkiewicz R. 1987. Wprowadrenie do apokryfón Starego Testamentu, Redakcja Wydawnictw Katolickiego Uniwersytetu Lubelskiego, Lublin.

/// Sesboüé B. 2006. Jezus Chrystus na obraz ludzi. Krótki przeglad przedstawień Jezusa na pržestrzeni dziejów, tłum. P. Rak, Wydawnictwo M, Kraków.

/// Sloterdijk P. 2013. Gorliwosí Boga. O walce træech monoteiżón, tłum. B. Baran, Wydawnictwo Aletheia, Warszawa.

/// Starowieyski M. 2006. Barwny świat apokryfów, Księgarnia św. Wojciecha, Poznań.

\section{/// Abstrakt}

Artykuł ma na celu analizę przekształceń symbolu religijnego. Jego rozmaite nieortodoksyjne użycia widoczne są m.in. we współczesnych narracjach apokryficznych. Teksty te, wykorzystujące postaci, motywy i symbole obecne w Piśmie Świętym, mają często charakter profanacji czy obrazoburstwa, lecz propagując treści stojące niejednokrotnie w sprzeczności z kanonem, paradoksalnie utrzymuja go w centrum semiosfery.

Analiza tego typu przekształceń pozwala dostrzec rolę, jaką symbol odgrywa w procesach autokomunikacji kultury, łącząc to, co tradycyjne, z tym, co nowe, a tym samym umożliwiając kulturze kontakt z przekazami źródłowymi. To szczególnie ważny bodziec do postrzegania tożsamości kulturowej jako ciagłej i spójnej.

Symbol jest najtrwalszym i najstarszym nośnikiem pamięci kulturowej, a jego przekształcenia (choćby były profanacją) wspomagaja jej pracę. Wchodząc w nowy kontekst nie traci on swoich poprzednich znaczeń, lecz nabywa nowe, ujawniając tym samym swe bogactwo semantyczne. Symbol jest zatem ważnym elementem dynamizującym kulturę i zapobiegającym jej petryfikacji.

Słowa kluczowe:

symbol religijny, profanacja, kanon, apokryf, pamięć kulturowa 


\section{/// Abstract}

The aim of the paper is to analyze transformations of the religious symbol. Various unorthodox uses of the symbol may be found in modern apocrypha. The texts utilize some biblical figures and motifs, which can be regareded as a profanity. Although their contents are often contradictory to the biblical canon, the traditional myth as it is presented in them paradoxically remains in the centre of the semiosphere.

An analysis of this kind of transformations of the religious symbol enables us to see the role it plays in the processes of cultural autocommunication. Those unorthodox uses connect the traditional with the modern and allow dynamically changing culture „to remember” its own roots. The fact that culture is able to communicate with itself is a basic condition of its cohesive identity.

The religious symbol is the oldest and most permanent medium of cultural memory and its transformations (profane or not) enhance the memory. As used in a new context, symbol does not lose its previous meanings but gains new ones instead. In the process its semantic wealth becomes apparent. The changes and reinterpretations of the symbol prevent the ossification of culture.

Keywords:

religious symbol, profanation, canon, apocrypha, cultural memory 